\title{
Dollars, Deficits, and the International Monetary System
}

$\mathrm{T}$

HE U.S. balance-of-payments deficit, according to most of the commonly used definitions, has reached record magnitudes in the past two years. Within the last several months, the persistence of large deficits has aroused sharp controversy both in official and private circles. For example, the Bank for International Settlements (BIS), in its latest Annual Report, commented in the following manner on the U.S. balance-of-payments situation: ${ }^{1}$

Apart from technical measures to contain the outflow of funds, the Administration had no plans for curing the U.S. payments deficit. The Council of Economic Advisers declared in its Annual Report that unilateral policy action by the United States cannot eliminate the deficit so long as other countries insist on running surpluses over and above their SDR allocations. This attitude seems rather far removed from the spirit - and the letter - of the Bretton Woods system, which SDRs are supposed to be preserving.

This brief statement touches certain sensitive areas of international monetary relations that are currently receiving considerable attention. First, and most urgent, are the problems of foreign countries, and in particular their central banks, in dealing with a huge influx of dollars. This large flow of dollars is partially a result of the reduction in U.S. borrowings from the Eurodollar market, and of the decline of interest rates in the United States." In addition, a "multiple expansion" of Eurodollars occurred as European central banks placed dollar balances with the BIS. Second, the balance-of-payments deficit of the United States is being reappraised in light of the policies of the Administration and in view of the prospects for improvement in the U.S. balance-of-payments position. Third, there is a new sense of urgency in the search for alternatives to the continued accumulation of dollars by foreigners, especially central banks. One possible solution, which has not received full consideration, calls for a U.S. policy of stable noninflationary monetary growth. These issues will be examined at length in this article.

1Bank for Irtternational Settlements, Foriy-first Annual Report, (Basel, 1971 ), p. 20.

${ }^{2}$ For an illuminating analysis of the Eurodollar market, see the immediately following article by Professor Milton Friedman

"The Eurodollar Market: Some First Principles," reprinted by pernission from the Morgan Guaranty Survey, October 1969.
As is generally the case in international monetary policy matters, these difficulties have little likelihood of quick resolution, although Germany and the Netherlands have attempted to meet their immediate dollar inflow problems by allowing their currencies to Hoat. Austria and Switzerland have revalued their currencies. ${ }^{3}$ The following article reviews recent issues and developments in international monetary affairs, and discusses some proposed measures to improve conditions.

\section{Europe's Dollar Problem}

\section{U.S. Interest Rates and Short-term Capital Flows}

Private foreigners have accumulated large amounts of dollars to hold as liquid assets and as a medium of exchange for world trade. Many foreigners have chosen to hold these liquid dollar balances as deposits in European banks (Eurodollars) rather than as direct deposits in U.S. banks. Extremely high Eurodollar interest rates encouraged private foreigners to channel currently accruing dollar receipts into Eurodollar deposits, especially in 1968 and 1969. Private foreigners also converted their domestic currencies into dollars for the same purpose, Foreign central banks, obligated to maintain fixed exchange rates, supplied these dollars by drawing down their official reserve holdings of dollars, and even sold $\$ 1$ billion of gold to the United States in order to obtain dollars in 1969. In addition, central banks themselves have been attracted by high interest yields, and have lent funds in the Eurodollar market through the Bank for International Settlements, which acted as an intermediary.

In large measure, the upward pressure on Eurodollar interest rates was transmitted by U.S. banks borrowing on a "nondeposit" basis in the Eurodollar market. Eurodollar interest rates normally rise and fall with U.S. short-term rates. In 1968 and 1969 , Eurodollar rates were also pushed up, as U.S. banks sought to find alternative sources of cash. The rise in U.S. short-term rates above existing interest rate ceilings had made it extremely difficult for banks to raise funds through the sale of negotiable CDs. With the

\footnotetext{
${ }^{3}$ A country that revalues raises the price, in terms of foreign currency, at which it buys or sells its own currency. A country that devalues does the opposite.
} 
decline in U.S. interest rates that began in early 1970 , and the removal of interest ceilings on large 30 - to 89-day maturity CDs in June 1970, U.S. banks once more were able to issue $\mathrm{CDs}$ at attractive rates, and

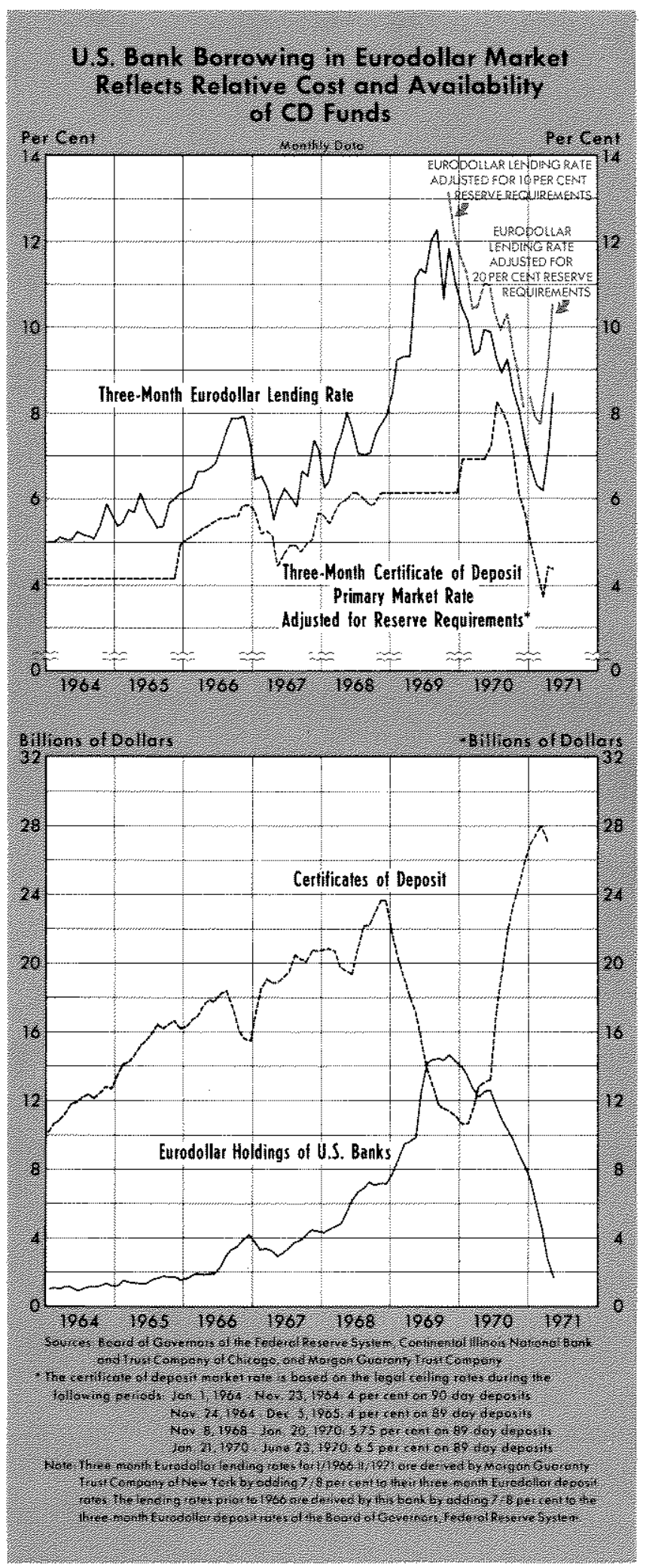

no longer found it profitable to compete for reserves in the Eurodollar market. The accompanying chart shows how the volume of CDs and Eurodollar borrowings of U.S. banks have fluctuated in response to $\mathrm{CD}$ interest rate ceilings and relative interest costs of obtaining funds in the two competing channels. As Eurodollar borrowings by U.S. banks were repaid, interest rates on Eurodollars declined sharply. Private foreigners then sought more attractive returns in domestic European money markets, and converted dollars back into European currencies through foreign central banks.

\section{The Mark-Dollar "Crisis"}

In West Germany, where the Bundesbank attempted to cool inflationary pressures by following a restrictive monetary policy, domestic interest rates were above Eurodollar interest rates by mid-1970, contrary to previous years. This induced German companies, which have free access to the Eurodollar market, to borrow funds from it, converting the dollar proceeds into marks. Multinational corporations and other investors were likewise encouraged to exchange dollars for marks which could earn attractive yields when placed on deposit in German banks or lent in German money markets. The following chart shows how German banks and enterprises increased their net foreign liabilities sharply in 1970 , as Eurodollar interest rates fell below domestic German rates.

As a result, the Bundesbank was obliged to purchase approximately 3 billion dollars between January and April in support of the official markdollar parity. The Bundesbank's dollar reserves grew, increasing expectations that official action would be taken to stem the inflow by adjusting upward the value of the mark. Conversion of dollars into marks by those in position to speculate on exchange rates then swelled the German central bank's dollar reserves even further, especially after official support of the dollar in forward exchange markets was suspended on April 28.

In just two days, before the foreign-exchange markets were temporarily closed on May 5 , the Bundesbank was forced to acquire an additional 2 billion dollars in order to maintain parity on the "spot" exchange market. ${ }^{4}$ Finally, on May 10 , the decision was announced that official dollar-mark convertibility

\footnotetext{
The spot exchange market involves trading of currencies for current delivery. Trading of currencies for future delivery is conducted in "forward" exchange markets. For an exposition of these terms, see Alchian and Allen, Untversity Economics (Belmont: Wadsworth Publishing Co., 1967), pp. 686-690, 753-760.
} 


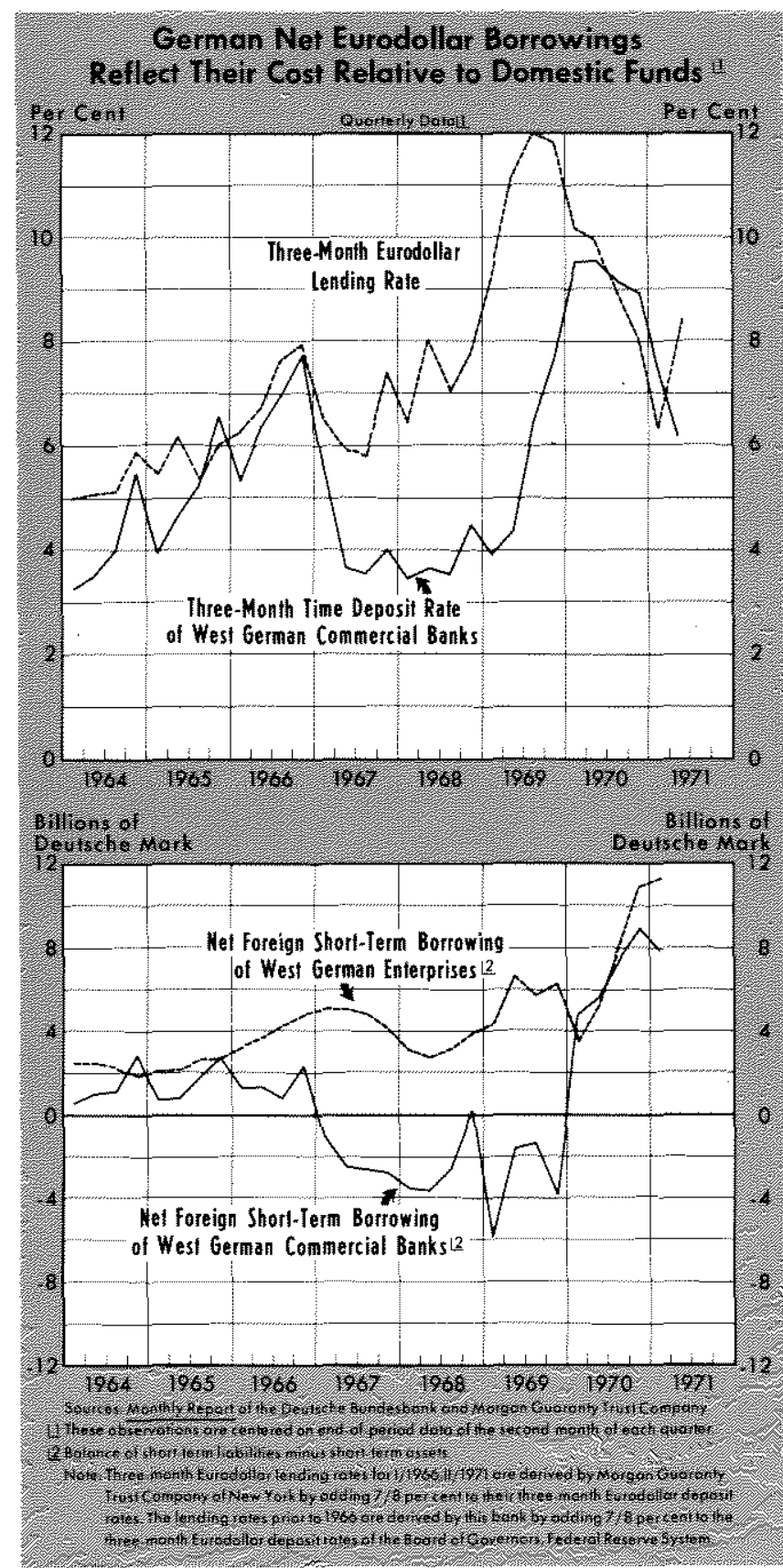

at 27.3 cents per mark was suspended for an indefinite period. Since then, the dollar price of the mark has fluctuated in the free market at a spot price ranging from two to five per cent above the old parity. Permitting the mark to float reduced the incentive for speculative conversion of dollars into marks.

German officials are apparently not unanimously agreed that an early revaluation is out of the ques. tion. Although a sharp improvement has occurred in 1971, some German officials point to their 1968-1970 balance-of-payments deficits ("basic balance") as evidence that a mark revaluation may be either unneces- sary or unwise. Some reports suggest the mark might be permitted to float for as long as six months or more until speculative sentiment wanes, after which the old parity might be restored. Recent accumulations of dollars due to short-term capital inflows are assumed by some officials to be temporary and reversible. The recent rise in Eurodollar lending rates may reduce the incentive for Germans to borrow Eurodollars.

Opposition to a revaluation of the mark stems from several industries, including German exporters of automobiles and machinery and import-competing industries, such as textiles, chemicals and electrical equipment. Revaluation of the mark by nine per cent in 1969 is still fresh in mind, and further appreciation might hurt the international competitive position of some German goods. Subsidized German agriculture, whose price support levels are geared to dollar equivalents under the European Economic Community (EEC) Common Agricultural Policy, stood to receive lower prices and incomes until assured that compensating adjustments in support levels and subsidies would be made.

\section{Shon merm Capial Glows and Monetary Stabiliation}

One of the advantages claimed for fixed exchange rates and free convertibility among currencies is that they tend to promote close international linkages among markets. These linkages pose certain monetary control problems, however. The mobility of shortterm capital, in response to interest rate differentials among countries, diminishes the leverage of foreign central banks in pursuing independent domestic monetary policies. Inflows of dollars into a given country tend to expand its monetary base, leading to faster growth in domestic money supply, easier credit conditions in the short run, and when resources become fully employed, to inflation and ultimately higher interest rates.

A monetary authority that seeks to prevent this must either discourage the inflow of dollars or offset the impact of the inflow on the domestic money supply through restrictive policies. But efforts to discourage the inflow of dollars may involve exchange controls and other interferences with markets. Restrictive monetary policies that temporarily result in higher domestic interest rates may actually tend to increase the inflow of dollars seeking short-term investment. Moreover, if the inflows are due, in part, to a favorable balance of trade, restrictive monetary policies will postpone, rather than hasten, the reduc- 
tion of exports relative to imports that would be required to restore balance-if-payments equilibrium.

Among the more frequently used methods for discouraging dollar inflows are: (a) central bank operations (frequently on a preferential basis with domestic commercial banks) to drive the price of the dollar upward in forward exchange markets so as to increase the "covered interest" rates on Eurodollar loans relative to interest rates on domestic loans; (b) reduction of central bank discount rates for the same purpose; (c) prohibition of interest payments to foreign owners of domestic bank deposits; (d) raising reserve requirements on such deposits; (e) exchange controls to limit the conversion of dollars into "resident" domestic currency; (f) capital restraints on the amount of foreign borrowing by domestic banks, other financial institutions and business firms; $(g)$ lowering of tariffs and other barriers to imports; and $(h)$ relaxation of restrictions on foreign investment by domestic individuals and companies. ${ }^{5}$

During the recent dollar-mark "crisis," West Germany, in order to discourage capital inflows, discontinued its operations in the forward exchange market, lowered its bank rate from seven and onehalf to five per cent, and stopped interest payments and doubled reserve requirements on foreign-owned bank deposits. Until now, West Germany has avoided direct controls of type (e) and (f), but the British Treasury recently prohibited additional short-term Eurodollar borrowing by British companies for domestic use.

The Japanese, who are currently running a balanceof-payments surplus, have maintained an extensive system of exchange controls to discourage short-term inflows of dollars. Opposition to yen revaluation is strong, so other measures to alleviate upward pressure are being adopted. Recently, the Japanese government announced an eight-point program that includes lower import barriers and complete liberalization of foreign investment by Japanese citizens and firms. Other actions have included lowering the central bank discount rate, relaxing controls on private ownership of dollars, and subsidizing banks desiring forward cover on dollar holdings.

Attempts to stem the flow of dollars into and out of central bank reserves have generally been ineffective or insufficiently vigorous. Therefore, in order to neutralize the effects of these movements on domestic spending, a somewhat different set of tactics has sometimes been adopted. To limit expansion of the

${ }^{5}$ George W. Mckenzie "International Monetary Reform and the "Crawling Peg," this Review (February 1969), pp. 15-23. domestic monetary base, some central banks have, on occasion, adjusted discount rates upward, liquidated their holdings of government securities, and raised commercial bank reserve requirements. Governments have sometimes increased their deposits at central banks. The leading practitioner of this general approach to dealing with recent dollar inflows has been France. The rates on Ioans and discounts at the Bank of France have been raised, taxes have been placed on bank deposits of foreigners, and reserve requirements have been increased. In West Germany, reserve requirements have been raised across the board on domestic bank deposits by 15 per cent. The Bundesbank in the past has been able to neutralize a high proportion of the changes in its foreign reserves through offsetting adjustments of the domestic sources of the monetary base.

Governments at times have also raised taxes, increased their borrowing, or undertaken other fiscal actions in support of these efforts. The German Federal budget for 1971 and commitments for funding future spending programs each have been cut by one billion marks.

If a country desires to maintain a fixed exchange rate, and finds it cannot prevent the accumulation of foreign exchange reserves or offset their effect on the domestic monetary stock, then the ultimate adjustment must be through changes in aggregate domestic demand, prices and interest rates. There is evidence that this has occurred in a number of instances. As world short-term capital markets become more closely linked, through the Eurodollar market and other transmission mechanisms, surplus and defcit countries will have less latitude to postpone these ultimate balance-of-payments adjustments. The present international system imposes a discipline on each country to foster a domestic price trend at a rate that, in the long run, is roughly consistent with the average for all trading nations. To some foreigners it appears more and more that this long-run average will be determined by the United States.

\section{When a Eurodollar Becomes a Dollar of Reserves}

The Eurodollar market has been blamed for accentuating the problems of central banks by increasing the mobility of short-term funds. There is reason

\footnotetext{
Ganfred Willms, "Controlling Money in an Open Economy: The German Case," this Review (April 1971), pp. 10-27. In 1969 and again this year, however, when the extremely large size of the inflows was due in part to speculation on revaluation, German monetary authorities made exchange rate adjustments.
} 
to believe, however, that these problems may have been aggravated partly by some of the central banks' own actions. As Table I indicates, in December 1970, recorded foreign exchange assets of central banks were $\$ 13.4$ billion greater than dollar and sterling liabilities to foreign central banks, as recorded by the United States and England, No less than $\$ 6$ billion of this discrepancy appeared in 1970 alone. Since the bulk of official foreign exchange reserves are dollars, and most of the remainder is sterling, the discrepancy has been attributed to a kind of "multiple counting" of dollar claims on the United States which arises out of central bank lending in the Eurodollar market.

Attracted by high yields on Eurodollars, a number of foreign central banks deposited dollars with the Bank for International Settlements (BIS), which in turn redeposited these funds with Eurobanks. ${ }^{7}$ After Eurobanks lent these deposited funds, some borrowers exchanged the dollar proceeds of the loans for foreign currencies obtained from central banks. The dollars that foreign central banks originally placed with the BIS became the basis for creation of new Eurodollars, some of which were acquired by central banks. Instead of counting as reserves only those dollars which are liabilities of the United States, the central banks counted some created liabilities of Eurobanks as well.

From the point of view of reconciling official central bank records of assets and liabilities, it is as if foreign central banks counted some of their true dollar claims on the United States twice (or possibly more times, in the case of Eurobank created dollars that were again fed back into the Eurodollar market). Unless offset by other actions, when these Eurodollars were converted into domestic currencies, foreign central banks would increase their domestic money supplies. There is little doubt that the willingness of central banks to supply funds to the Eurodollar market supported multiple expansion of Eurodollar deposits. It may also have kept Eurodollar interest rates lower than they otherwise would have been.

Realization of the extent to which Eurodollars have been recycled in this manner is very recent. Some estimates suggest that at least $\$ 5$ billion of foreign official dollar reserves have been generated in this way. ${ }^{8}$ The BIS has confirmed the intention of central

TEurobanks are banks located outside the United States (including foreign branches of U.S. banks) which accept deposit liabilities denominated in dollars.

${ }^{8 F}$ ritz Machlup, "The Magicians and Their Rabbits" Morgan Guaranty Surcey (May 1971), pp. 3-13.

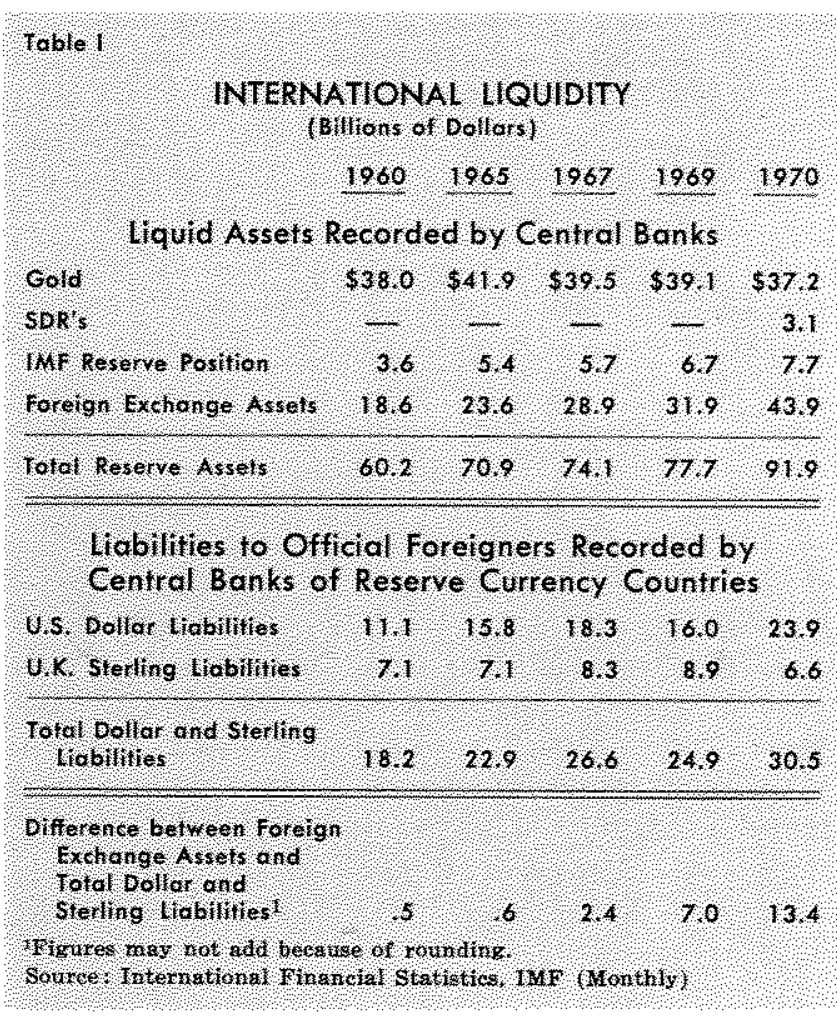

banks to withdraw funds from the Eurodollar market "when such action is prudent in the light of market conditions." Quick withdrawal of funds might drive Eurodollar rates up, causing contraction of the Eurodollar borrowing.

It is not surprising in light of these discoveries that many international monetary officials are now calling for regulations on Eurodollar banking. There has been conjecture about imposing reserve requirements on Eurodollar deposits. Unless these are made uniform and universal, opposition may be forthcoming, particularly from the British. About half of such Eurobanking is conducted in London, and uneven application of regulations might result in loss of some of this market to other countries.

\section{U.S. Balance of Payments}

\section{Balanceof wanments Pollcies}

The recent upheaval in foreign exchange markets disturbed a calm that had prevailed over the international financial system since the 1969 mark revaluation. Except for strong disapproval of the use of exchange rate adjustments as an instrument of shortrun domestic cyclical control, ${ }^{9}$ responses to the current mark-dollar crisis among U.S. officials have been

\footnotetext{
Speech by Arthur Burns, Chairman, Board of Governors of the Federal Reserve System, before the International Banking Conference, Munich, May 28, 1971.
} 
restrained. Administration spokesmen have acknowledged a concern over controlling the size of the "basic" balance-of-payments deficit, ${ }^{\text {to }}$ which specifically excludes short-term dollar flows that have been the source of recent unrest. Some foreign observers have been prompted to accuse the present Administration of pursuing a policy of "benign neglect" toward its balance-of-payments deficits. ${ }^{11}$ While U.S. international monetary policy has not been materially modified in the light of recent events, it is incorrect to describe the United States as responding completely passively to the build-up of dollars in official foreign hands.

Last December, the Federal Reserve attempted to encourage banks to maintain their Eurodollar "reserve free base" liabilities by raising reserve requirements on liabilities in excess of this base from 10 per cent to 20 per cent. In an effort to push up Eurodollar interest rates relative to rates in other foreign money markets, the Export-Import Bank between January and April borrowed $\$ 3$ billion from foreign branches of U.S. banks. The U.S. Government paid almost a two percentage point premium for such funds over comparable U.S. short-term interest rates. According to Federal Reserve Governor Dewey Daane, the Federal Reserve and the Treasury also undertook a mild revival of "operation twist," emphasizing purchase of coupon issues to restrain long-term rates from rising while issuing short-term debt to exert upward pressure on short-term rates. ${ }^{12}$ As a further step, announced in June, the Treasury would exchange $\$ 5$ billion of short-term Treasury securities held by the German Bundesbank for higher yielding medium-term securities.

Beyond this, the reaction of some officials to foreign criticism that more should be done has been to emphasize that by reducing inflationary pressures, the restrictive monetary policies of 1969 and early 1970

10 Speech by Paul A. Volcker, Under Secretary of the Treasury, before the joint meeting of the American Economic, Finance, and Statistical Associations, Detroit, December 29, 1970. "The "basic" balance is the sum of: (a) the current account balance; (b) the balance on long-term U.S and foreign private capital; and (o) the balance of U.S. and foreign government capital other than changes in U.S. and foreign official reserve holdings.

11A policy of "benign neglect" by the U.S. of its balance-ofpayments deficits has been advocated in two recent articles: Gottried Haberler and Thomas D. Willet, A Strategy for U.S. Balance of Payments Policy, American Enterprise Institute for Public Policy Research (February, 1971), and Lawrence B. Krause, "A Passive Balance-of-Payments Strategy for the United States," Brookings Papers on Economic Activity, Volume 3,1970 .

12Speech by Dewey Daane, Member of the Board of Govemors, Federal Reserve System, before the Bankers' As. sociation. for Foreign Trade, Boca Raton. Florida, April 27,1971 . have, in fact, contributed to improved international stability. Continuance of tight money, it is felt, not only might weaken the U.S. economy, but depress our demand for imported goods to the point of plunging the rest of the world into serious economic contraction. The Vice-President of the United States expressed it bluntly when he said, "We will not . . . put the United States through the wringer in order to deal with a temporary situation." 13 Ironically, the recent low interest rates, of which Europeans complained, were substantially the result of previous tight U.S. monetary policies, which led to a weakening in demand for credit.

There seems to be an inclination of U.S. policymakers to assign to other countries some of the responsibility for our balance-of-payments deficits. The United States, it is maintained, cannot succeed in reducing its payments deficits if other countries are determined to follow policies that enable them to have surpluses. Chairmant Arthur Burns of the Federal Reserve has called upon foreign countries to relax their import restraints and capital investment controls, and to use fiscal policy more actively in domestic stabilization. Citing the excessively stringent monetary policies conducted by European countries in the past year, Dr. Burns advised these countries to coordinate their monetary policies more closely with the requirements for stabilization of international shortterm capital flows. ${ }^{14}$ Proposals that the United States arrange somehow to devalue the dollar with respect to other major currencies have made little headway. Administration leaders have, in turn, suggested that some foreign currencies may be undervalued. ${ }^{15}$

\section{The U.S. Balance of Payments in Petrospect}

The U.S. balance of payments (on a liquidity basis) has been in deficit in all but two years since 1950 the year the Korean War began and one year after most major currencies underwent major devaluations with respect to the dollar. Until the last three years of the Eisenhower administration, these deficits were generally small and aroused no great concern among

${ }^{13}$ Speech by Vice President Spiro Agnew, before the Business Council, Hot Springs, Virginia, May 8, 1971, as reported in the Wall Street Journal (May 10, 1971).

14Testimony by Arthur Burns before the Senate Banking Committee, May 19, 1971, as reported in the New York Joumal of Commerce (May 20, 1971).

15Testimony by John Connally, Secretary of the Treasury, before the Senate Finance Subcommittee, May 17, 1971, as reported in the New York Journal of Commerce (May 20, 1971). Also see Annual Report of the Council of Economic Advisers, Economic Report of the President, 1971 , p. 152 . 
policymakers. By 1959, however, our balance of payments had become a problem that called for, and received, corrective treatment in the form of a restrictive monetary policy. In the wake of the 1960-61 recession, the economy operated below capacity for several years. Inflation, which had accelerated between 1955 and 1958, was brought under control. Wholesale prices, for example, did not increase at all between 1960 and 1964, compared with a 1.9 per cent average increase for the other major industrial countries. Along with this improved price performance came somewhat reduced balance-of-payments deficits, largely because our exports expanded faster than our imports. In 1964 the current account balance reached a surplus of $\$ 5.8$ billion, the highest it had been since 1947 .

The benefits of monetary restraint during the late 1950 's and early 1960 's were not fully reflected in the balance of payments, owing to increasingly large outflows on long-term capital account. Long-term net U.S. foreign investment exceeded $\$ 4$ billion in both 1964 and 1965 and had risen steadily from $\$ 1.6$ billion in 1959. Direct and portfolio investment in the Common Market countries of Europe was largely responsible for this increase. Congress enacted the interest equalization $\operatorname{tax}$ in 1964 to discourage borrowing by foreign corporations in U.S. money markets. Restrictions on foreign lending were imposed on banks and other financial institutions in 1965. Voluntary controls on direct investment abroad by American corporations were imposed in 1965 and made mandatory in 1968.

While the capital controls program served to reduce the outflow of long-term funds in the latter half of the 1960's, the U.S. current account surplus began to shrink after 1964. By 1968 it had become a deficit of $\$ 0.4$ billion. Again, relative trends of prices at home and abroad had a telling impact. Expansive monetary policies created substantial inflation in the United States beginning in 1965. U.S. wholesale prices advanced at 2 per cent annually between 1964 and 1968, compared with 1.4 per cent for other industrial countries. The increase in direct U.S. overseas military expenditures from $\$ 2.9$ billion in 1964 to $\$ 4.5$ billion in 1968 was another factor contributing to the smaller balance on current account. Between 1968 and 1970 , however, wholesale prices in other major countries increased more rapidly than corresponding U.S. prices ( 4.2 versus 3.2 per cent, respectively); the U.S. balance of payments on current account showed only slight further weakening in 1969 and improved in 1970.
Capital Hows became the dominant factor causing changes in our balance-of-payments position during 1969 and 1970. Increased net outflows on long-term capital account contributed $\$ 1$ billion of the $\$ 1.5$ billion increase in the "basic" balance-of-payments deficit in 1969. Our "net liquidity" deficit rose in 1969 to $\$ 6.1$ billion from $\$ 1.6$ billion the previous year. Most of this change could be accounted for by: (a) imperfections in the balance-of-payments statistics related to transfers of deposits to Eurobanks; ${ }^{16}$ (b) reduction in purchases of U.S. stocks and bonds by private foreigners; and (c) lessened growth in non-liquid short-term foreign borrowing by U.S. businesses. The "official settlements" balance, which reflects changes in foreign official net dollar claims, showed a surplus of $\$ 2.7$ billion in 1969, mainly because private foreigners, seeking high interest returns available on Eurodollars, converted their domestic currencies into dollars at foreign central banks, thus causing a decrease in official foreign holdings of dollars.

With the decline in U.S. interest rates in 1970, unrecorded transfers of deposits to the Eurodollar market by U.S. individuals dropped sharply. This, plus the initial SDR allocation to the U.S., combined to cut the net liquidity deficit to $\$ 3.9$ billion. Improvement in the current account balance was offset by an increase in our deficit on long-term capital account, so that the "basic" balance-of-payments deficit was slightly larger in 1970. The fall in U.S. interest rates brought about a decline in Eurodollar interest rates, which led to a huge conversion of dollars into local currencies by private foreigners. As liquid dollar holdings of foreigners were shifted from private to official hands, the official settlements deficit reached $\$ 9.8$ billion, compared with a surplus in the previous year.

\section{Shont-Run Prospects}

Expansion of the domestic economy at a pace faster than foreign economic expansion tends to carry with it an increase in demand for imports relative to exports, and a deterioration of the balance of payments on current account. Consequently, a weakening of our balance of payments might seem to be in prospect, as the U.S. economy recovers from the $1969-70$ recession. U.S. imports may be stimulated by rising domestic incomes. Our excess of exports over imports, after reaching a seasonally adjusted annual

${ }^{16}$ A substantial volume of deposits transferred by Americans from U.S. banks to foreign branches were not recorded as increasing our liquid assets, but the simultaneous borrowing of these funds by U.S. banks from their foreign branches was recorded as increasing our liquid liabilities. 
rate of $\$ 2.7$ billion in the first three quarters of 1970 , shifted to one-quarter of this rate in the six months ended March 1971.

Although this smaller trade surplus is traceable mainly to rapid expansion of imports relative to exports, there are disturbing signs that demand for our exports may deteriorate because a number of important trading nations are now encountering economic slowdown. Industrial production indexes for France, Italy, and Germany have levelled off since the second quarter of 1970, while Japan's industrial growth began to decelerate in the fourth quarter. Unemployment has increased in all of these countries since 1969. British industrial production has been moving erratically upward, but unemployment remains relatively high. In the year ended fourth quarter 1970 , wholesale prices in the United States rose 2.8 per cent, compared with 4.5 per cent in other major industrial countries. However, with a business expansion underway in the United States and ecom nomic slowdown occurring in other major trading countries, the forces that recently have moved the relative price trend in our favor may not continue. Upward adjustment of the value of the mark (floating), guilder (floating), Austrian schilling (revalued 5.05 per cent), and Swiss franc (revalued 7.07 per cent) will help, but very little. The effect of adjustments made so far would be to reduce the relative prices of American goods and services in world markets by well under one per cent on average.

This emphasis on imports and exports fails to take into consideration cyclical forces whose infuences on the capital account are opposite to their influences on the current account. It International flows of shortterm capital have become highly sensitive to interest rate differentials among countries, and have tended to exercise a powerful influence on short-run fluctuations in the U.S. balance of payments. As the accompanying chart shows, capital account changes have frequently more than offset current account changes. The dominance of capital flows has been especially evident since 1968.

In the first quarter of 1970 , our balance-of-payments deficit, on an official settlements basis, reached a seasonally adjusted annual rate of $\$ 22.1$ billion; on a net liquidity basis the deficit was more than $\$ 10.4$ billion. These deficits were among the largest ever recorded, and reflected speculative outflows and a

\footnotetext{
77 The balance of payments on current account includes all transactions involving exports and imports of goods and services and transfer payments. The capital account, as used here, consists of all private transactions in assets and liabinities, whether classified in the balance-of-payments as long-term, short-term, nonliquid or liquid.
}

very sharp decline in U.S. and Eurodollar interest rates. Speculative movements of funds may have al. ready diminished, and if the domestic economy expands faster than foreign economies, there will be a rise in domestic interest rates relative to those overseas. Short-term rates in the United States have already risen substantially from their February lows. The cyclical upswing in interest rates can be held in check only temporarily by an exceedingly expansive monetary policy, and such a policy will ultimately result in even higher interest rates.

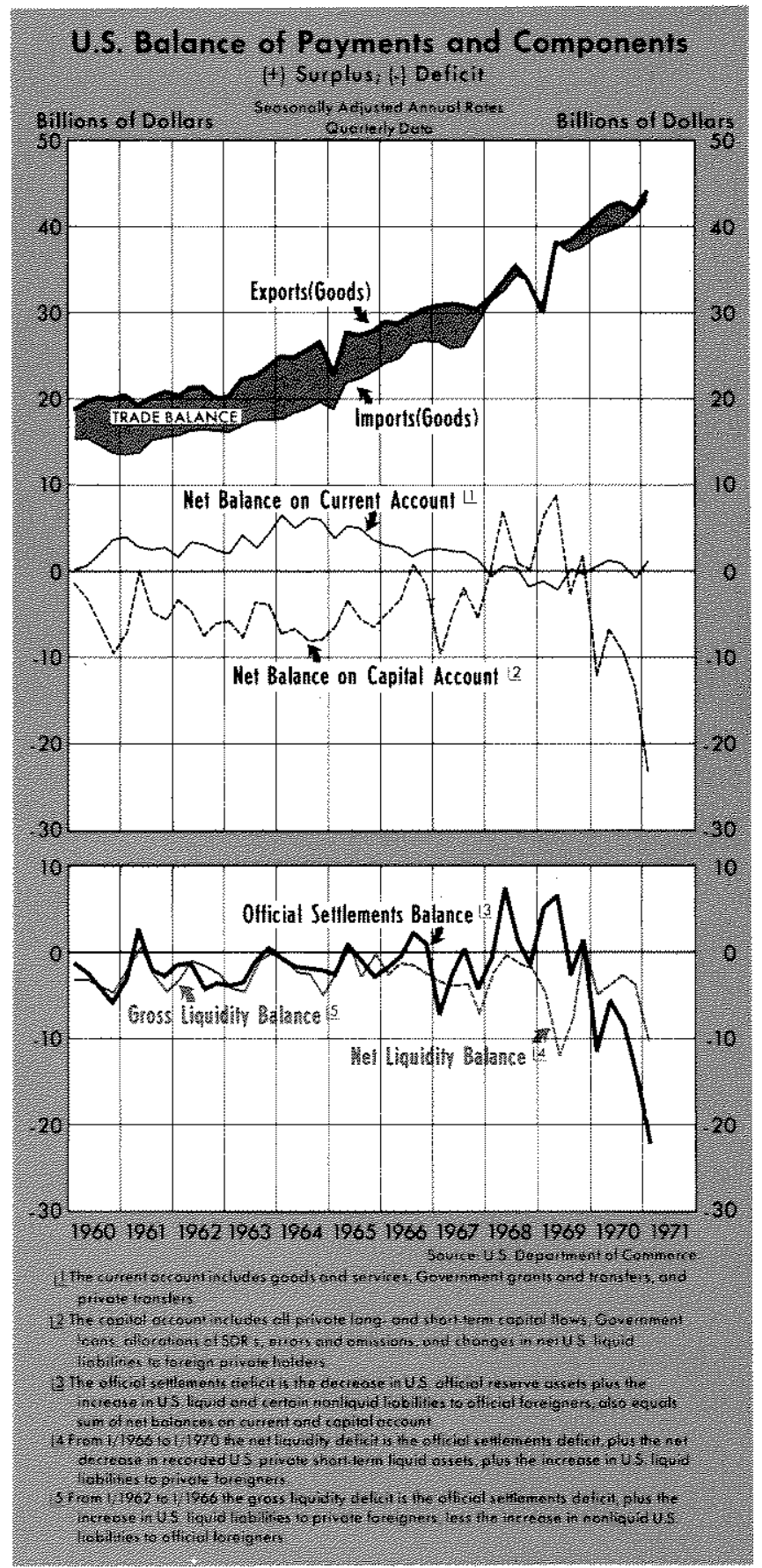


Forces are therefore operating once again to make short-term investment in the United States relatively attractive to foreigners, and short-term foreign investment less attractive to Americans. Long-term foreign investment in the United States, although modest in comparison with overseas long-term asset acquisitions by U.S. investors, has also begun to recover from the low levels of the first half of 1970. If recent performance is any guide, the favorable swing in the capital account could outweigh the deterioration of the current account, so that the U.S. balance-of-payments position, on both the official settlements and liquidity balance basis, might soon improve.

\section{Proposed Alterations to Present International Monetary Arrangements}

The large flow of dollars into foreign central banks, and the decision to allow the mark to doat, touched off a new round of diagnoses of the problems in managing the present international monetary system. These ranged from warnings of the impending collapse of the entire system, to enthusiastic approval of recent developments as demonstrations of progress toward greater exchange rate flexibility.

The system being reappraised is the product of central bank adherence to International Monetary Fund (IMF) rules. The effect of these rules has been (a) to reinforce the United States' commitment to redeem on demand in gold at $\$ 35$ per ounce all official foreign dollar claims, and (b) to induce other individual governments, to maintain, for long periods, fixed parity prices of dollars in terms of their own currencies. In recent years, foreign central banks, with few exceptions, have avoided exercising their gold conversion option. ${ }^{18}$ A foreign central bank, if it wishes to continue supporting the price of the dollar in terms of its own currency at the existing exchange parity, must be willing to absorb as reserves whatever dollars are offered to it. As the "dollar standard" has evolved, with discretion for monetary growth lodged in U.S. hands, foreign governments would face inflationary pressures should U.S. monetary and fiscal actions persistently take an excessively expansive course. On the other hand, in the short-run, dollar flows may be erratic and create diffcult problems of economic stabilization for foreign governments.

\footnotetext{
1. Germany has mot purchased gold from the U.S. since 1964. France recently obtained $\$ 282$ million, but has been a net seller to the U.S. since 1966 . The U.K. has international. francial obligations which make it an mankely potentiak purchaser of gold. Canada, despite strong balance-of-payments surphuses, has veen selling gold as a producer nation. Japan last bought U.S. gold in 1966. Among major industrial nations, only the Low Contrties and Switzerland frequently exercise their gold comversion option.
}

\section{Ratse the Dollar Price of Gold?}

Foreign reactions to this dilemma have therefore been directed toward finding viable alternatives to present intemational monetary arrangements. One option advocated at times - devaluation of the dollar in terms of gold - has been losing support. Five years ago, when dollar claims held by foreigners were perhaps no more than twice as large as the U.S. gold stock, it was possible to give serious consideration to a doubling of the dollar price of gold (which would double the dollar value of our gold stock) as a means of restoring U.S. ability to meet all dollar claims at a fixed gold price. Now that total foreign official and private liquid dollar claims are more than three times as large as our gold stock, as shown in Table II, the required threefold increase in the price of gold is beyond reasonable probability of adoption. ${ }^{19}$ The tremendous gains from such a change in the official gold

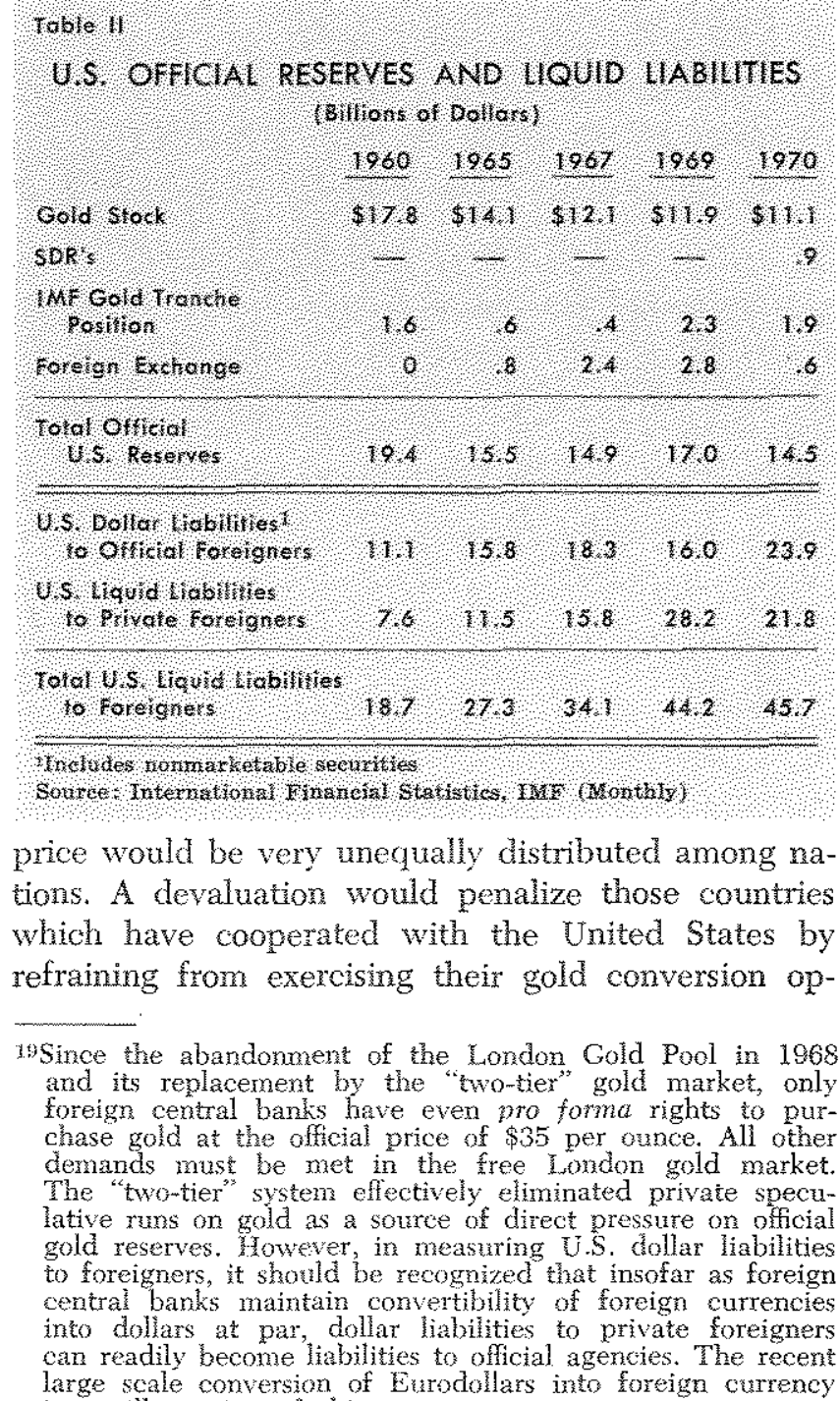

price would be very unequally distributed among nations. A devaluation would penalize those countries which have cooperated with the United States by refraining from exercising their gold conversion op-

wince the abandonment of the London Gold Pool in 1968 and its replacemert by the "wo-ter" gold market, only foreign central banks have even pro forma rights to purchase gold at the official price of $\$ 35$ per ounce. All other demands must be met in the free Lomdon gold market. The "two-tier" system effectively eliminated private speculative rums on gold as a source of direct pressute on official gold reserves. However, in measturing U. 5 . dollar liabilities to foreigners, it should be recognized that insofar as foreign central banks maintain convertibility of roreign currencies inco dollars at par dollar liabinities to private foreigners can readily become liabilities to official agencies. The recent large scale conversion of Eurodollars into fortign currency is an illustration of this. 
tion. Gold producers would benefit a great deal from this devaluation; in 1968 South Africa supplied 76.8 per cent of the world's gold output.

\section{More " ${ }^{\text {Paper Gold" }}$ ?}

Another alternative is to place greater reliance on paper gold, that is, Special Drawing Rights. A major criticism of the present system is that dependence on dollar deficits as a source of additions to international liquidity is an unreliable and erratic device for controlling growth in the world's monetary reserves. It has even been suggested that there is paradox in a system in which growth in the supply of dollars is greatest when U.S. balance-of-payments deficits are the largest. Confidence in the "soundness" of the dollar may then be weakest. As confidence lessens, the demand for dollars would be reduced. Shifts in the supply and foreign private demand for dollars as international currency may be inversely related. This might tend to magnify domestic instability of countries that adhere to fixed exchange rates, since their central banks would be forced to acquire dollars that private foreigners do not want. The problems of maintaining control over the domestic money supply in the face of large dollar flows have been discussed previously.

Under the present de facto dollar standard, a variety of emergency credit facilities have been provided for countries under temporary balance-of-payments pressure. These arrangements include the following: (a) currency "swap" agreements, arranged by the Federal Reserve, which permit the central banks of 14 major countries limited lines of credit to borrow each other's currencies for periods up to one year; (b) IMF quotas which permit members to draw, for pe riods up to five years, fund currencies in amounts equal to their 25 per cent IMF gold contribution ("tranche") on demand, and their 75 per cent domestic currency contribution with IMF permission; and (c) emergency lending commitments of the "Group of Ten" large trading nations to come to the aid of countries in liquidity crisis when other credit facilities are inadequate.

The international monetary system has been criticized by those who believe that neither the existing conditions under which dollars are supplied nor these emergency credit arrangements satisfactorily provide for stable growth in international liquidity. For this reason, the expansion of Special Drawing Rights (SDRs) ${ }^{20}$ and quotas in the IMF has been

\footnotetext{
${ }^{\circ}$ SDRs are allocated by the IMF to its members. Title to SDRs can be transfered from one member to another in exchange for convertible currency, which can then be used in settlement of balance-of-payments deficits. Each member country initialy receives SDR "allocations" in proportion to its subscribed quota in the IMF, and agrees to accept
}

advocated. So far, IMF members have agreed to the allocation of $\$ 9.4$ billion of SDRs; $\$ 3.4$ billion were issued on Jantaary 1, 1970 and $\$ 3$ billion each on January 1, 1971 and 1972. Negotiations on additional allocations will begin next year.

Two features of SDRs deserve emphasis, First, they are intended to substitute for gold as an ultimate means of settling balance-of-payments deficits. Since SDRs can be created by a weighted 85 per cent majority of the voting members of the IMF, shortages of intemational liquidity, such as might arise if gold production were the only source of new international reserves, can in principle be eliminated by international agreement to allocate additional SDR s-a simple bookkeeping operation.

Secondly, SDRs can substitute for dollars as an intemational reserve currency. Instead of being a fortuitous by-product of U.S. balance-of-payments deficits, as some critios describe the present situation, the creation of additional reserve currency can be made a matter of international planning and agreement on the long-run rate of growth of world liquidity. Potentially, the growth in international currency reserves could be rendered more stable. ${ }^{21}$

\section{Greater Thexbilly of Exchange Rates?}

Broader recognition of the extent to which present arrangements based on pegged exchange rates reduce the monetary autonomy of individual countries has recently sparked an unprecedented amount of discussion and experimentation concerning increased flexibility of exchange rates. West Germany's decision to allow the mark to float is the second in less than two years. An important prelude to the more recent of these actions was a unanimous report by five private German economic research institutes advocating

additional SDRs (upon request of the IMF, and in exchange for its own currency) up to twice its own cumulated SDR allocation. Each nember country pays interest on its cumulated allocation, and receives interest on all SDRs held A cointry whose cumelated allocation exceeds its holdings of SDRs will be a net payer of interest; one whose holdings exceeds its allocation will be a net recipient of interest. See Michael Keran, "A Dialogue on Special Drawing Rights," this Review (July 1968), pp. 5-7.

21.Also, each country can share in the seigniorage benefits of liquidity creation in proportion to its quota in the IMF. These benefits now accrue to the United States insofar as it is the supplier of reserve currency to the world. Seigniorage is received if the interest paid to holders of international reserve assets is less than the monetary yield such holders colld earn on other assets. The interest paid on SDR $s$ is 1.5 per cent per year, which is considerably less than the average interest paid on dollar claims. 


\section{Flexible Exchange Rates}

The ease for llexible exchange trtes is very similar to the case for free anregulated competitive markets in other contexts t nakets would he deared without rationing substales or stockpiling. An cutonatie inechansm is promided for acheving latance-ol-payments equilibrim through dijusiment of relative pref. and cost levels of imports and expoits rather than through tuemitative controls ar Minstients of domeste prico and cost levels. Most importantly. flextble exehange rates diminate the batance of pay. ments as a serious constraint on the use of momefary. and Ascat policy to pursue donestie ceconomic stabil iration objuctives. Restrutions: on fres movement of goods, services and capital icross frontiers would no longer be instifable because of the bilanee of pavments

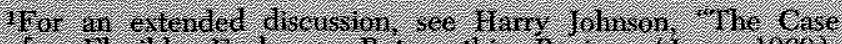

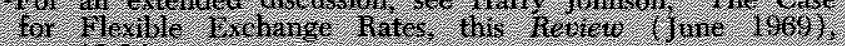
11. . . 124 critics of exchange rate llextbilty oftem liave tec. ogrized is theoretieat virtues as an automatic adiustment mechanim, but have raised practical objections rolited to (a) the possible destallizing dfects of specthators on exelange rates, and (b) the discouragement to intemutiomal trade and nvestment from inereased meertainty will respect to furme exchangs rates. The first objection iests on the mistaleed assumption that spectiators can, in the aggregate, derive profts by driving exchange rates athay from heir equilibium levels. The second oljection falls to allows for development of forvind mirkets in forcign ex

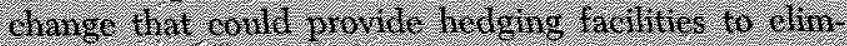
inate uncertainty with respect to trale and short-term eapital transactions: As for long terin capital trans: actions, the present systems mixture of exchange controls, spectal taxes, and periodic exchange trle adjushinents provides no greater centainty and te. liablity than would a flexille exchange rate systen ? perhaps less. that the mark be allowed to float to determine a new exchange rate - a report which was termed "constructive" by West German Economics Minister Schiller. The guilder was also allowed to float at the same time as the mark. In June 1970, Canada returned to a floating rate, after a lapse of eight years. This year the U.S. Council of Economic Advisers voiced approval of "greater flexibility of exchange rates within the framework of the present system established at Bretton Woods." 2.2 Treasury Secretary Connally, in a recent speech in Munich, suggested that consideration be given to incorporating additional elements of flexibility of exchange rates into the present system. ${ }^{23}$ Against this background, the international financial community awaits with interest the IMF's first major study of floating rates. ${ }^{24}$

The principal objection to a system of flexible exchange rates remains a practical one - it has never been tried on a sufficiently widespread scale, under sufficiently normal worldwide economic conditions, to justify the claims made for it (or against it). If progress toward freeing exchange rates is to be made,

22Annual Report of the Council of Economic Advisers, Economic Report of the President, 1971, p. 145.

23Speech by John Connally before the International Banking Conference, Mmich, May 28 , 1971, as reported in The American Banker (June 1, 1971), p. 16.

24International Monetary Fund, Annual Report, 1970, p. 14. it may therefore evolve within the present system which, despite its weaknesses, provides a known, agreed-upon organizational and procedural framework.

Two major steps that could be implemented, if present IMF rules were modified, would be (a) to widen to as much as 5 per cent, from the present 1 per cent band, the permissible margins around parity within which each country's exchange rates could vary; and (b) to permit smaller and more frequent changes in parity levels. Since, even now, the IMF concurs in parity adjustments whenever these are necessary to correct a "fundamental disequilibrium," the IMF itself could establish criteria that would encourage such adjustments. For example, although rejected in the past, the IMF might still adopt the "crawling peg" proposal, under which the parity level would be a continuously adjustable moving average of recent past market exchange rates, appreciating if the currency had previously tended to sell at its "ceiling" level, and depreciating if it had tended to sell at its "floor" level.

Measures are being taken or proposed which could undermine adherance to and support for IMF "adjustable peg" policies. Aside from the actions of Canada, Germany, and the Netherlands, Belgium has modified its "two-tier" system, so as to maintain a fixed ex- 
change rate on current account transactions, while permitting the exchange rate on a wider range of capital transactions to float. Other countries are reported to be considering similar measures. Another possibility would be the conlescing of national currencies into two or more "key currency" blocs, whose respective national currencies would exchange at fixed rates within the bloc, and at luctuating rates with respect to currencies in other blocs. The reported German proposal for a "concerted float" of all EEC currencies against the dollar is a step in this direction. A floating rate against the dollar might be required if a common EEC currency unit and monetary policy, now plamed for 1980 , is to be achieved. Alteration of the IMFs operating rules may therefore become necessary if it is to play an influential role in guiding the future course of international monetary organization.

\section{Stable Monetary Growth and the Dollar's Role as a Key Currency}

In recent years, the dollar reserves of foreign central banks have been subjected to sharp variations, due to changes in the willingness of private foreigners to hold dollars. Fluctuations in U.S. interest rates were largely responsible for these variations in demand for dollars. These interest rate movements were, in turn, ultimately attributable to wide swings in the growth rate of the U.S. money supply. As a result, foreign central banks have found it difficult to control the growth in their own domestic money stocks in the face of fluctuations in their dollar reserves. Unsteady inflows of dollars under fixed exchange rates are viewed by some foreign governments as a serious impediment to successful pursuit of their domestic economic stabilization policies.

The 1971 Annual Report of the Council of Economic Advisers asserts that. . "inconsistency of balance-of-payments goals [among countries] cannot, in short, be solved through wilateral policy action by the United States." Instead, says the Report, ". . . it requires multiateral action by the members of the International Monetary Fund."25 Interpreting this passage broadly, it seems to deny that there is any policy the United States could alone undertake which would provide a fully adequate foundation for a stable, non-inflationary international monetary system.

The present international position of the dollar as a reserve currency and liquid asset makes it an alternative to any reserve currency (such as SDRs)

95 Economic Report of the President, 1971, p. 151. that might be created by intemational agreement. In order for the dollar to achieve an acceptable position as an intemational reserve currency, however, two conditions must be fulfilled. First, the purchasing power of the dollar in terms of goods and services must not be subject to rapid and unpredictable erosion that might impair its attractiveness as a liquil asset. Second, the stock of dollars used as international currency should grow at a stable rate, so that the dollar reserves of foreign monetary anthorities may expand at a reasonably steady rate.

These requirements might appear to pose an excessively burdensome constraint on the exercise of discretionary power by U.S, monetary authorities. Yet, there is mounting evidence that efforts at discretionary monetary management have increased, rather than reduced, instability of domestic aggregate demand. More often than not, this instability has bern associated with unsuccessful attempts by the Federal Reserve to manipulate interest rates (or money market conditions) instead of concentrating on the provision of moderate, steady growth in monetary aggregates, such as the money supply. The paradox of the more aggressive discretionary "contracyclical" U.S. monetary management of the past five years is that it has produced procyclical results, including wider fluctuations in monetary growth, interest rates, and final demand, as well as faster inflation. Insofar as unstable U.S. monetary growth in the past five years has resulted in increased fluctuations in our interest rates and economic conditions, relative to those abroad, the U.S. balance of-payments position has also fluctuated more widely-especially compared with the results of the less variable monetary policies of the previous five years.

There is no evidence of an inherent conflict between the goals of a stable noninflationary intemational monetary system and a stable U.S. economy. Steady, non-infationary growth in the U.S. money supply would appear to serve both objectives very effectively. Under such a program of steady monetary growth, the problem of removing inconsistencies between other countries' balance-of-payments policies and our own, could, with justification, be considered the responsibility of other countries to correct. Increased stability of the U.S. economy would lessen U.S. short-term cyclical interest rate fluctuations and would tend to reduce short-term capital flows now caused by these interest rate fuctuations. Increased domestic U.S, price stability would help preserve the attractiveness of the dollar as a liquid asset. 
Under more stable conditions in the United States, some foreign countries might find it advantageous to maintain fixed parity values of their currencies in terms of dollars. The monetary policies of such nations could then be geared to steady expansion of their domestic money supplies at rates that would maintain balance-of-payments equilibrium with the United States. A pattern of price stability similar to the United States is very likely to develop in such countries.

On the other hand, countries that found such accommodation to be difficult or undesirable could maintain balance-of-payments equilibrium and pursue independent monetary policies by permitting the exchange value of their currencies, relative to the dollar, to adjust freely in the foreign exchange market. Yet, even for such countries, the very stability of U.S. monetary growth would foster an international monetary environment less subject to external shocks and uncertainty. There would therefore be little reason to expect the policies of the United States to be conducive to widely fluctuating ex* change rates. There would be still less reason for such countries to resort to direct controls on capital or current account transactions to protect their domestic economy from the effects of U.S. policy on the world economy.

In the view of many of its proponents, the fundamental appeal of the gold standard was the protection it afforded against rapid inflation, and the automatic mechanism it provided for expansion of the world money supply through new gold production. Before World War I, the great financial prestige of the United Kingdom supported the gold standard. No multilateral negotiations were necessary - each country adopted the gold standard or abstained, as it saw fit. The maintenance of a steady, moderate rate of monetary growth by the United States can offer the advantages of a gold standard more reliably and at less cost in real resources. Moreover, such a "dollar standard" could, through voluntary and piecemeal adaptation by individual nations, become the basis for a stable international monetary system, without the negotiations, stalemates, compromises, and makeshift agreements that inevitably accompany multilateral efforts to reform the present system.

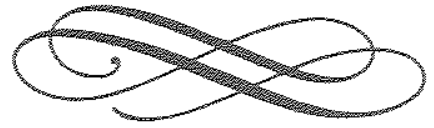

